\title{
DIMINISHING OF STEEL CORROSION IN ACID ENVIRONMENT USING THIN BI-LAYER SURFACES OF MONO-CARBOXYL-SUBSTITUTED $\mathrm{A}_{3} \mathrm{~B}$ PORPHYRIN AND $\mathrm{MnTa}_{2} \mathrm{O}_{6}$
}

\author{
${ }^{1}$ Mihaela BIRDEANU, ${ }^{2}$ Aurel-Valentin BIRDEANU, ${ }^{3}$ Ion FRATILESCU, \\ $3^{*}$ Eugenia FAGADAR-COSMA \\ ${ }^{1}$ National Institute for Research and Development in Electrochemistry and Condensed Matter, Timisoara, \\ Romania, mihaelabirdeanu@gamil.com \\ ${ }^{2}$ National Research \& Development Institute for Welding and Material Testing - ISIM, Timisoara, Romania, \\ valentinbirdeanu@yahoo.com \\ 3Institute of Chemistry "Coriolan Dragulescu", Timisoara, Romania, \\ efagadar@yahoo.com,ion.fratilescu@gmail.com
}

https://doi.org/10.37904/nanocon.2021.4373

\begin{abstract}
It is already known, that porphyrin-bases are offering better protection against steel corrosion than metalloporphyrins due to their ability to form very stable metallic complexes by linking in their inner core the iron contained in different steels. In this respect, 5-(4-carboxy-phenyl)-10,15,20-tris-(4-phenoxy-phenyl)porphyrin was synthesized by multicomponent Adler-Longo synthesis, using two different aldehydes and pyrrole, characterized to certify the structure and further used for formulating double thin layers in all possible combinations with $\mathrm{MnTa}_{2} \mathrm{O}_{6}$. The pseudo-binary oxide nanomaterials $\mathrm{MnTa}_{2} \mathrm{O}_{6}$ were synthesized by solidstate method. The corrosion protection exhibited by these nanostructures alone or in composites after deposition on carbon steel was comparatively assessed in acid environment. Different electrochemical techniques, such as: open circuit potential measurement and potentiodynamic polarization technique with Tafel representation were used. The performed tests reveal that corrosion protection is fairly good, with the best results indicating that the electrode covered with 5-(4-carboxy-phenyl)-10,15,20-tris-(4-phenoxy-phenyl)porphyrin $/ \mathrm{MnTa}_{2} \mathrm{O}_{6}$ has offered the best corrosion inhibition efficiency of 86.05
\end{abstract}

Keywords: Mono-carboxyl-substituted $\mathrm{A}_{3} \mathrm{~B}$ porphyrins, $\mathrm{MnTa}_{2} \mathrm{O}_{6}$, steel, corrosion inhibition, Tafel curves

\section{INTRODUCTION}

Corrosion protection plays a prominent role in several sectors, such as: marine infrastructures, oil and gas industries, aircrafts and transportations systems [1,2]. Corrosion direct impact on different industrial sectors is magnified by the higher additional costs [3-6]. The use of inhibitors is one of the most practical methods for protection against corrosion in aggressive media as acid medium [7]. Metal corrosion leading to the degradation of metal properties is due to the interaction of metals with certain elements in the environment, this being a normal and inevitable process [8]. During time, porphyrins and/or pseudo-binary oxides demonstrated their qualities as corrosion inhibitors [9] Recent attempts have been made to clarify the influence of the nature of pseudo-binary oxide and/or porphyrins, used for protective thin films, and the deposition order onto steel with the purpose to finally improve the corrosion inhibition of steel in different environments [9-11]. For a long time manganese has been extensively used in various steels, batteries, non-ferrous metal alloys and scientific research [12], due to its versatility. Tantalum has attracted attention for corrosion inhibition applications destined for chemical and biomedical industries due to its excellent results obtained in several aggressive environments [13,14]. 
The present study it's about investigations concerning the inhibition of corrosion in $1 \mathrm{M} \mathrm{HCl}$ media for $\mathrm{MnTa}_{2} \mathrm{O}_{6}$ pseudo-binary oxide and 5-(4-carboxy-phenyl)-10,15,20-tris-(4-phenoxy-phenyl)-porphyrin thin layers deposited by drop-casting technique on modified steel electrodes, in single or sandwich type structures. The porphyrin used in this study was chosen due to its already proven self-organization properties that provide multi lamellar triangles, uniformly in shape, dimensions and orientation that uniformly cover the surface.

\section{MATERIALS AND METHODS}

The pseudo-binary oxide nanomaterials $\mathrm{MnTa}_{2} \mathrm{O}_{6}$ were synthesized by solid-state method. The starting materials used during the synthesis were: tantalum (V) oxide - $\mathrm{Ta}_{2} \mathrm{O}_{5}(99.99 \%$, Merck), and manganese (VI) oxide $-\mathrm{MnO}_{2}\left(99.99 \%\right.$, Sigma-Aldrich). The mixture of oxides was afterwards heated at $1200^{\circ} \mathrm{C}$ for $3 \mathrm{~h}$ soaking time.

The $A_{3} B$ mono substituted $\mathrm{COOH}$-porphyrin, 5-(4-carboxyphenyl)-5,10,15-tris(4-phenoxyphenyl)-porphyrin, might be obtained in several ways: by hydrolysis of ester type Zn-metalloporphyrins [15], or by applying Adler -Longo multicomponent reaction based on the condensation of pyrrole and two different structured benzaldehydes 4-carboxylmethylbenzaldehyde and 4-phenoxybenzaldehyde in a particular ratio of 4:3:1, as previously reported [16] The methyl ester was hydrolyzed in basic condition followed by neutralization with diluted $\mathrm{HCl}$ [17].

Both tested materials, $\mathrm{MnTa}_{2} \mathrm{O}_{6}$ pseudo-binary oxide and 5-(4-carboxy-phenyl)-10,15,20-tris-(4-phenoxyphenyl)-porphyrin were used to obtain single and sandwich type structures by drop casting technique on carbon steel (OL) disks electrodes $(10 \mathrm{~mm}$ diameter and $2 \mathrm{~mm}$ thick). The deposition order and the combinations of the layers in the sandwich structures are presented in Table 1.

Table 1 Drop casting thin film depositions

\begin{tabular}{|l|l|l|}
\hline Sample & \multicolumn{1}{|c|}{ Deposition order } & \multicolumn{1}{|c|}{ Deposition Mode } \\
\hline a & $\mathrm{MnTa}_{2} \mathrm{O}_{6}$ & Single structure \\
\hline b & 5-(4-carboxy-phenyl)-10,15,20-tris-(4-phenoxy-phenyl) porphyrin & Single structure \\
\hline c & 5-(4-carboxy-phenyl)-10,15,20-tris-(4-phenoxy-phenyl) porphyrin / $\mathrm{MnTa}_{2} \mathrm{O}_{6}$ & Sandwich structure \\
\hline d & $\mathrm{MnTa}_{2} \mathrm{O}_{6} /$ 5-(4-carboxy-phenyl)-10,15,20-tris-(4-phenoxy-phenyl) porphyrin & Sandwich structure \\
\hline
\end{tabular}

The morphology and the particle dimensions of the samples were investigated by SEM / EDAX (Model INSPECT S) and AFM (Model Nanosurf EasyScan2 Advanced Research) using the noncontact mode cantilever (scan size of $1.1 \mu \mathrm{m} \times 1.1 \mu \mathrm{m}$ ).

The electrochemical measurements were realized using a Voltalab potentiostat (Model PGZ 402) coupled with a three electrode electrochemical cell, comprised of: bare (OL) or drop casting modified alloy steel tubes disk as working electrode, a platinum wire as counter electrode and a satured calomel electrode as reference electrode (SCE). The working electrodes were mounted in a Teflon body to ensure a controlled active surface. The potentiodynamic polarization measurements were recorded at $23{ }^{\circ} \mathrm{C}$, by sweeping the potential in the $1.3 \mathrm{~V} \div-0.6 \mathrm{~V}$ range at a scan rate of $1 \mathrm{mV} / \mathrm{s}$. The open circuit potential (OCP) of the modified electrodes was monitored for 30 minutes before polarization. The electrolyte solution used for the corrosion tests was $1 \mathrm{M} \mathrm{HCl}$. The degree of inhibition efficiency (IE\%) were calculated based on equation (1) [18].

$I E \%=\left(1-\frac{i_{\text {corr }}}{i_{\text {corr }}^{0}}\right) \times 100$

where $i_{\text {corr }}^{0}$ and $i_{\text {corr }}$ represent the values of the current density in the absence and in the presence of the pseudo-binary oxide/porphyrin films, respectively. 
Disks of bare electrode carbon steel (OL) containing (wt\%) $0.10-0.35 \% \mathrm{Si}, 0.07-0.13 \% \mathrm{~S}, 0.70-1.10 \% \mathrm{Cr}$, $0.12-0.18 \% \mathrm{C}, 0.03 \% \mathrm{P}$ and $98.21-98.98 \% \mathrm{Fe}$ were employed as working electrodes.

The carbon steel surfaces were polished to a mirror-like surface finishing using emery paper (granulation diameter $2000 \mu \mathrm{m}$ ), rinsed with distilled water and degreased in ethanol, before each thin film deposition by drop casting.

\section{RESULTS AND DISCUSSION}

The morphological aspects of the resulting thin films were comparatively examined by SEM, as shown in Figure 1, recorded for various single and sandwich structures based on combinations of pseudo-binary oxides and porphyrins before the corrosion tests. At the surface of the thin films can be noticed the formation of some irregular agglomerates heavily compacted structures of particles with dimensions in the range of $500 \div 1000$ $\mathrm{nm}$ (Figures $\mathbf{1} \mathbf{a}$ and $\mathbf{b}$ ). Also, for the sandwich structures (Figures $\mathbf{1} \mathbf{c}$ and $\mathbf{d}$ ) is observed a larger density of the particles at the surface of the thin films than for the single layers.

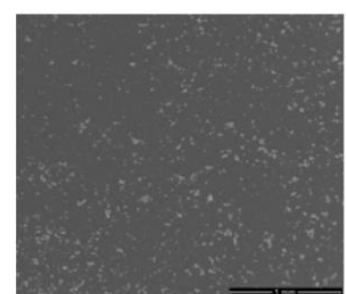

a)

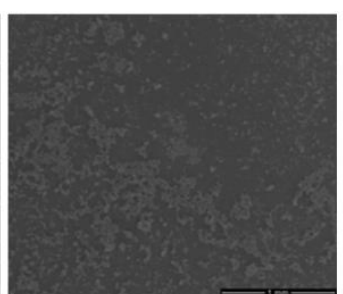

b)

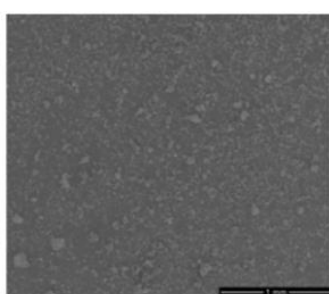

c)

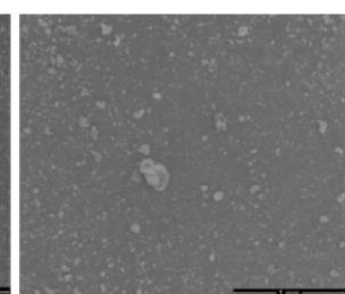

d)

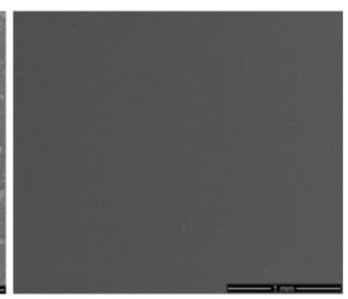

e)

Figure 1 The SEM images of: a) $\mathrm{MnTa}_{2} \mathrm{O}_{6}$; b) 5-(4-carboxy-phenyl)-10,15,20-tris-(4-phenoxy-phenyl) porphyrin; c) 5-(4-carboxy-phenyl)-10,15,20-tris-(4-phenoxy-phenyl) porphyrin / $\mathrm{MnTa}_{2} \mathrm{O}_{6}$; d) $\mathrm{MnTa}_{2} \mathrm{O}_{6}$ / 5-(4carboxy-phenyl)-10,15,20-tris-(4-phenoxy-phenyl) porphyrin; e) OL(bare electrode)

Topographic analysis for the obtained thin films of $\mathrm{MnTa}_{2} \mathrm{O}_{6}$ pseudo-binary oxide with 5-(4-carboxy-phenyl)10,15,20-tris-(4-phenoxy-phenyl)-porphyrin was perfomed using atomic force microscopy (AFM). The recorded 3D images are presented for each thin film obtained by the drop casting method according with Figures 2a-d. Figure 2 e shows the carbon steel electrode $(\mathrm{OL})$ before deposition. Besides particle size analysis, AFM measurements were also used to determine the surface roughness. Using the NanoSurf EasyScan 2 computer program, the surface roughness for each sample was calculated according to [18], using the equations for the average roughness $\left(S_{a}\right)$ and the mean square root roughness $\left(S_{q}\right)$-for each deposited layer onto steel electrodes.

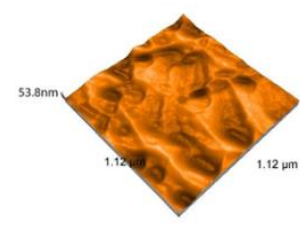

a)

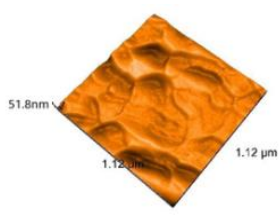

b)

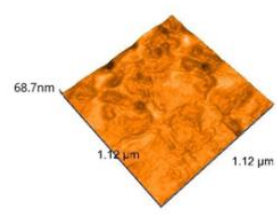

c)

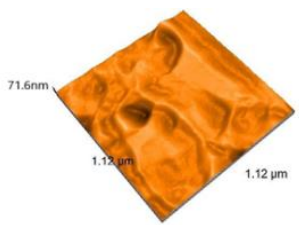

d)

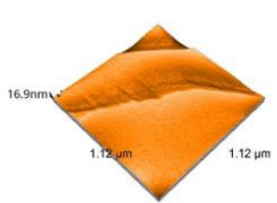

e)

Figure 2 3D AFM images for the depositions of: a) $\mathrm{MnTa}_{2} \mathrm{O}_{6}$; b) 5-(4-carboxy-phenyl)-10,15,20-tris-(4phenoxy-phenyl) porphyrin; c) 5-(4-carboxy-phenyl)-10,15,20-tris-(4-phenoxy-phenyl) porphyrin / $\mathrm{MnTa}_{2} \mathrm{O}_{6}$;

d) $\mathrm{MnTa}_{2} \mathrm{O}_{6} /$ 5-(4-carboxy-phenyl)-10,15,20-tris-(4-phenoxy-phenyl) porphyrin; e) OL(bare electrode)

The particle dimensions and the nanorugosities were calculated for all the depositions (Table 2) using the AFM software. 
From Table 2 it was observed that the smallest roughness value was obtained for $\mathrm{MnTa}_{2} \mathrm{O}_{6}$ single layer and the values were increasing in case of depositing sandwich layers (larger values being obtained for 5-(4carboxy-phenyl)-10,15,20-tris-(4-phenoxy-phenyl) porphyrin / $\mathrm{MnTa}_{2} \mathrm{O}_{6}$ sandwich layers of $13.90 \mathrm{~nm}$ ).

It was found that the size of the particles at surface (Table 2) significantly varies between 14.26 and $43.1 \mathrm{~nm}$. The largest size for particles was obtained at the surface of the $\mathrm{OL}$ modified with $\mathrm{MnTa}_{2} \mathrm{O}_{6}$ layers.

Table 2 The particle dimension and calculated nanorugosities at the depositions' surfaces

\begin{tabular}{|c|c|c|c|c|c|}
\hline Sample & $\begin{array}{c}\text { Area } \\
(\mathrm{pm} 2)\end{array}$ & $\begin{array}{c}S_{a} \\
(n m)\end{array}$ & $\begin{array}{c}S_{q} \\
(\mathrm{~nm})\end{array}$ & $\begin{array}{c}S_{y} \\
(\mu \mathrm{m})\end{array}$ & $\begin{array}{c}\text { Particles dimension } \\
(\mathrm{nm})\end{array}$ \\
\hline OL & \multirow{5}{*}{1.326} & 1.43 & 2.37 & - & - \\
\hline a & & 3.64 & 4.65 & 27.29 & 43.1 \\
\hline b & & 7.54 & 9.52 & 66.72 & 26.9 \\
\hline$c$ & & 13.90 & 17.96 & 113.4 & 14.26 \\
\hline d & & 10.10 & 12.57 & 81.56 & 20.2 \\
\hline
\end{tabular}

The evolution of the OCP function of time was analyzed for the bare and modified steel disk electrodes, in $1 \mathrm{M}$ $\mathrm{HCl}$ electrolyte solution, for $30 \mathrm{~min}$ and are presented in Figure 3a. The drop- casting deposited layers determined the shifting the OCP of the electrodes toward more positive values, compared with the bare OL electrode. This analyze provides preliminary information on the nature of the processes occurring at the protected metal interface with electrolyte. The OCP measurements (Figure 3a) showed that the thin films obtained with porphyrins (5-(4-carboxy-phenyl)-10,15,20-tris-(4-phenoxy-phenyl) porphyrin, $\mathrm{MnTa}_{2} \mathrm{O}_{6} / 5$-(4carboxy-phenyl)-10,15,20-tris-(4-phenoxy-phenyl) porphyrin and 5-(4-carboxy-phenyl)-10,15,20-tris-(4phenoxy-phenyl) porphyrin / $\mathrm{MnTa}_{2} \mathrm{O}_{6}$ ) were stabilized around $500 \mathrm{~s}$, while the thin film obtained from pseudobinary oxide $\left(\mathrm{MnTa}_{2} \mathrm{O}_{6}\right)$ stabilizes around $800 \mathrm{~s}$.

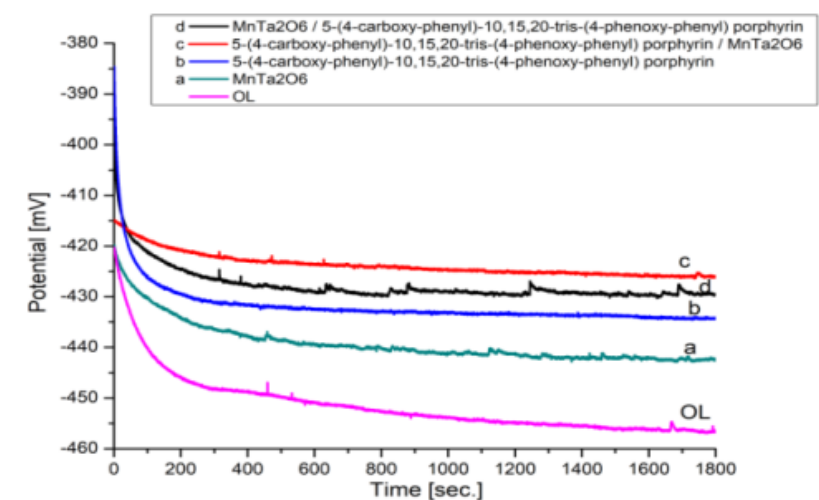

a

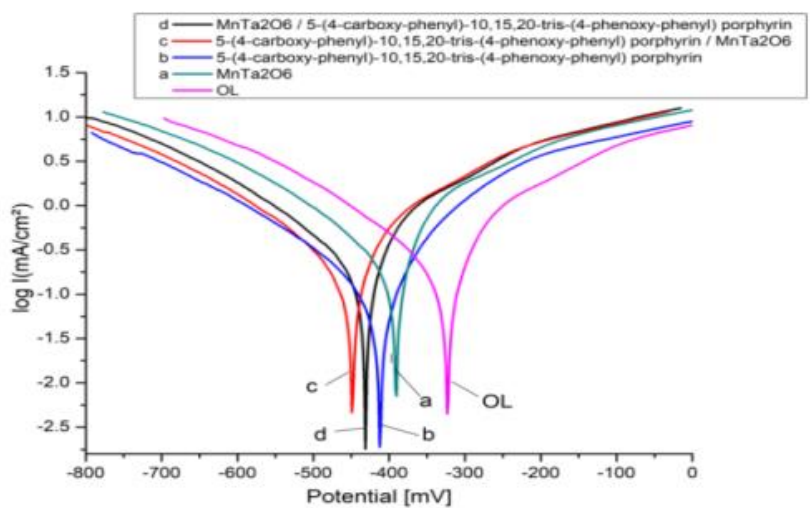

b

Figure 3 a) Evolution of OCP and b) Tafel representation of polarization curves recorded in $1 \mathrm{M} \mathrm{HCl}$ for the investigated electrodes for: OL (bare electrode), a) $\mathrm{MnTa}_{2} \mathrm{O}_{6}$; b) 5-(4-carboxy-phenyl)-10,15,20-tris-(4phenoxy-phenyl) porphyrin; c) 5-(4-carboxy-phenyl)-10,15,20-tris-(4-phenoxy-phenyl) porphyrin / $\mathrm{MnTa}_{2} \mathrm{O}_{6}$; d) $\mathrm{MnTa}_{2} \mathrm{O}_{6} /$ 5-(4-carboxy-phenyl)-10,15,20-tris-(4-phenoxy-phenyl) porphyrin;

The potentiodynamic cathodic and anodic polarization curves measured in $1 \mathrm{M} \mathrm{HCl}$ solution, after 30 minutes stabilization of OCP, are presented in Figure $\mathbf{3 b}$ and the electrochemical parameters obtained from the Tafel extrapolation are summarized in Table 3. It is noticed that the corrosion rates decrease for all modified steel electrodes comparing with the corrosion rate for bare electrode. The degree of inhibition efficiency IE (\%) has 
been calculated on the basis of equation reported in [19]. By corroborating all the obtained results, it was observed that the highest inhibition efficiency of $86.1 \%$, that is a fair result, was obtained in the case of the thickest film deposition 5-(4-carboxy-phenyl)-10,15,20-tris-(4-phenoxy-phenyl) porphyrin / $\mathrm{MnTa}_{2} \mathrm{O}_{6}$ (see Table 2) which also presents the highest value of the roughness (see Table 2), meaning that defects in the protective layers do not create centers for corrosion. The values of the inhibition efficiencies are obviously influenced by the thickness of the protective layers, meaning that the mechanism of protection is mainly of physical nature.

Table 3 The Tafel parameters calculated for the investigated electrodes, after 30 min immersion in $1 \mathrm{M} \mathrm{HCl}$ solution

\begin{tabular}{|c|c|c|c|c|c|}
\hline Sample & $\begin{array}{l}E_{\text {corr }} \\
(\mathrm{mV})\end{array}$ & $\begin{array}{c}\mathbf{R p} \\
\left(\Omega \mathrm{cm}^{2}\right)\end{array}$ & $i_{\text {corr }}\left(\mathrm{mA} / \mathrm{cm}^{2}\right)$ & $\begin{array}{c}v_{\text {cor }} \\
\left(\mathrm{mm} / \mathrm{Y}^{1}\right)\end{array}$ & $\begin{array}{l}\text { IE } \\
(\%)\end{array}$ \\
\hline OL & -406.3 & 101.35 & 0.9548 & 3.256 & - \\
\hline a & -410.7 & 110.22 & 0.3781 & 2.635 & 60.4 \\
\hline$b$ & -416.1 & 120.03 & 0.1623 & 1.669 & 83 \\
\hline c & -418.6 & 256.73 & 0.1331 & 1.345 & 86.1 \\
\hline d & -415.4 & 137.71 & 0.1557 & 1.629 & 83.7 \\
\hline
\end{tabular}

It was found that the corrosion potential $E_{\text {corr }}$ decrease from $-406.3 \mathrm{mV}$ (the corresponding current density $i_{\text {corr }}$ $\left.=0.9548 \mathrm{~mA} / \mathrm{cm}^{2}\right)$ for the bare $\mathrm{OL}$ to $-418.6 \mathrm{mV}\left(i_{\text {corr }}=0.1331 \mathrm{~mA} / \mathrm{cm}^{2}\right)$ for the depositions with 5-(4-carboxyphenyl)-10,15,20-tris-(4-phenoxy-phenyl) porphyrin as the first layer and $\mathrm{MnTa}_{2} \mathrm{O}_{6}$ as the second layer. The highest polarization resistance $(R p)$ increase from $101.35 \Omega \cdot \mathrm{cm}^{2}$ for bare $\mathrm{OL}$ to $256.73 \Omega \cdot \mathrm{cm}^{2}$ which corresponds to the sandwich structure with the highest $I E$.

\section{CONCLUSION}

The purpose of this study was to realize new combinations of materials (porphyrins and pseudo-binary oxides) with efficiency in corrosion inhibition of steel in acid medium. $\mathrm{An}_{3} \mathrm{~B}$ porphyrin, 5-(4-carboxy-phenyl)-10,15,20tris-(4-phenoxy-phenyl)-porphyrin was synthesized by multicomponent Adler-Longo synthesis. $\mathrm{MnTa}_{2} \mathrm{O}_{6}$ pseudo-binary oxide nanomaterials were obtained by solid-state method. Both materials were deposited by drop casting method on carbon steel electrodes, in order to realize synergistic protective properties. Corrosion tests were performed by electrochemical measurements in $0.1 \mathrm{M} \mathrm{HCl}$ acid solution. For all the modified electrodes with drop-casted layers an improvement of the corrosion inhibition was observed. The OL modified with deposited layers of 5-(4-carboxy-phenyl)-10,15,20-tris-(4-phenoxy-phenyl) porphyrin / $\mathrm{MnTa}_{2} \mathrm{O}_{6} \mathrm{Showed}$ the best corrosion inhibition efficiency (over $86 \%$ ). So, the sandwich layer with the lower particle dimension offered the best result.

\section{ACKNOWLEDGEMENTS}

This work was supported by grant of the Romanian Ministry of Research, Innovation and Digitization/UEFISCDI, project number PN-III-P2-2.1-PED-2019-0487, 528PED/2020, CeraPor and partially by Romanian Academy through Programme 3/2021 from Institute of Chemistry "Coriolan Dragulescu".

\section{REFERENCES}

[1] AGHILI, M., YAZDI, M. K., RANJBAR, Z., JAFARI, S. H. Anticorrosion performance of electro-deposited epoxy/ amine functionalized graphene oxide nanocomposite coatings. Corrosion Science. 2021, vol. 179, p.109143. 
[2] CHANG, C.-H., HUANG, T.-C., PENG, C.-W., YEH, T.-C., LU, H.-I, HUNG, W.-I, WENG, C.-J., YANG, T.-I, YEH, J.-M. Novel anticorrosion coatings prepared from polyaniline/graphene composites. Carbon. 2012, vol. 50, no. 14, pp. 5044-5051.

[3] International, N. Assessment of the global cost of corrosion. Available from: http://impact.nace.org/economicimpact.aspx.

[4] NIKPOUR, B., RAMEZANZADEH, B., BAHLAKEH, G., MAHDAVIAN, M. Synthesis of graphene oxide nanosheets functionalized by green corrosion inhibitive compounds to fabricate a protective system. Corros. Sci. 2017, vol. 127, pp. 240-259.

[5] MALIK, M. A., HASHIM, M. A., NABI, F., AL-THABAITI, S. A., KHAN, Z. Anti-corrosion Ability of Surfactants: A Review. Int. J. Electrochem. Sci. 2011, vol. 6, pp. 1927 - 1948.

[6] LU, X., LIU, L., XIE, X., CUI, Y., OGUZIE, E. E., WANG, F. Synergetic effect of graphene and Co (OH) 2 as cocatalysts of TiO2 nanotubes for enhanced photogenerated cathodic protection. J. Mater. Sci. Technol. 2020, vol 37, pp. 55-63.

[7] SARI, M.G., RAMEZANZADEH, B. Epoxy composite coating corrosion protection properties reinforcement through the addition of hydroxyl-terminated hyperbranched polyamide non-covalently assembled graphene oxide platforms. Constr. Build. Mater. 2020, vol. 234, p. 117421.

[8] TAN, B., HE, J., ZHANG, S., XU, C., CHEN, S., LIU, H., LI, W. Insight into anti-corrosion nature of Betel leaves water extracts as the novel and eco-friendly inhibitors. Journal of Colloid and Interface Science. 2021, vol. 585, pp. 287-301.

[9] BÎRDEANU, A. V., BIRDEANU, M., FAGADAR-COSMA, E. Corrosion protection characteristics of ceramics, porphyrins and hybrid ceramics/porphyrins, deposited as single and sandwich layers, by pulsed laser deposition (PLD) J. Alloys Compds. 2017, vol. 706, pp. 220-226.

[10] BIRDEANU, M., BÎRDEANU, A.V., VAIDA, M., MILOVANOVIC, D., LASCU, A., FAGADAR-COSMA, E. Corrosion behaviour of ZnTa2O6 pseudo-binary oxide, zinc meso-tetra (4-pyridyl) porphyrin (ZnTPyP) and hybrid ZnTa2O6/ZnTPyP layers deposited by PLD. Phys. Scr. 2019, vol. 94, p. 075702

[11] BIRDEANU, M., BIRDEANU, A. - V., VAIDA, M., ORHA, C., FAGADAR-COSMA, E. Anticorrosive properties of ZnTa2O6 and ZnV2O6 nanomaterials - deposited as sandwich structures by drop casting method - in $\mathrm{NaCl}$. In: Conference Proceedings 9th International Conference on Nanomaterials - Research \& Application, NANOCON 2017, Brno, Czeh Republic: Tanger, 2018, pp. 359-365,

[12] CAO, Z.-F., WANG, J., QIU, P., YANG, F., WANG, S., LIU, G., ZHONG, H. Hydrophobic coatings for improving corrosion resistance of manganese substrate. Surface \& Coatings Technology. 2018, vol. 347, pp. $235-244$.

[13] LU, F., CAO, Z.-F., YANG, F., WANG, S., ZHONGA, H. Fabrication of hydrophobic coating on electrolytic manganese surface for enhancing corrosion resistance. Progress in Organic Coatings. 2019, vol. 132, pp. 379387.

[14] HU, W., XU, J., LU, X., HU, D., TAO, H., MUNROE, P., XIE, Z.-H. Corrosion and wear behaviours of a reactivesputter-deposited Ta2O5 nanoceramic coating. Applied Surface Science. 2016, vol. 368, pp. 177-190.

[15] BELINE, T., DE AlMEIDA, A. B., NETO, N. F. A., MATOS, A. O., RICOMINI-FILHO, A. P., SUKOTJO, C., SMEETS, P. J. M., DA SILVA, J. H. D., NOCITI, JR F. H.,. BARAO, V. A. R. $\beta$-Ta2O5 thin film for implant surface modification triggers superior anticorrosion performance and cytocompatibility of titanium. Applied Surface Science. 2020, vol. 520, p. 146326

[16] BAKAR, M.B., OELGEMOLLER, M., SENGE, M.O. Lead Structures for Applications in Photodynamic Therapy. Part 2 Synthetic Studies for Photo-Triggered Release Systems of Bioconjugate Porphyrin Photosensitizers. Tetrahedron. 2009, vol. 65, pp. 7064-7078.

[17] MAK, C. A., PERICAS, M. A., FAGADAR-COSMA, E. Functionalization of A3B-type porphyrin with Fe3O4 MNPs. Supramolecular assemblies, gas sensor and catalytic applications. Catalysis Today. 2018, vol. 306, pp. $268-275$.

[18] AHMAD Z. Principles of Corrosion Engineering and Corrosion Control. Butterworth-Heinemann/IChemE Series. Elsevier, Amsterdam, 2006, vol. 377.

[19] KAPAKLIS, V., POULOPOULOS, P., KAROUTSOS, V., MANOURAS, TH., POLITIS, C. Growth of thin Ag films produced by radio frequency magnetron sputtering. Thin Solid Films. 2006, vol. 510, p. 138. 